\title{
ANALISIS KEGIATAN DAN PERSEPSI MAHASISWA CALON GURU BIOLOGI TERHADAP KEGIATAN KULIAH PRAKTIK LAPANGAN ZOOLOGI VERTEBRATA
}

\author{
Sri Maryanti*1, S. Sa' ${ }^{\prime}{ }^{2}{ }^{2}{ }^{2}$, M.Sholehah ${ }^{3}$ \\ 1,2,3Jurusan Pendidikan Biologi, Fakultas Tarbiyah dan Keguruan UIN Sunan Gunung Djati, \\ Bandung 40614 \\ Email: *1Sri.maryanti@uinsgd.ac.id
}

Doi: https://doi.org/10.31943/mangiferaedu.v4i1.35

Received: 29 Juni $2019 \quad$ Accepted: 13 Agustus 2019 Published: 23 Agustus 2019

Citasi: Maryanti, S.,Sa'adah, S., \& Sholehah, M. (2019). Analisis Kegiatan Dan Persepsi

Mahasiswa Calon Guru Biologi Terhadap Kegiatan Kuliah Praktik Lapangan

Zoologi Vertebrata. Jurnal Mangifera Edu. 4(1): 32-45.

\begin{abstract}
The purpose of this study was to determine student perceptions of vertebrate zoological field study at LIPI Cibinong. The research method used is a descriptive method with survey techniques. The survey was conducted on 52 students of Biology Education department at UIN SGD Bandung. The results showed that $80.2 \%$ of students gave positive perceptions of vertebrate zoology field study because according to the students this field study could increase the meaningful learning, expand knowledge about vertebrate zoology, and strengthen the intimacy between students. Also, students believe that the field study is an implementation of Edutainment activities.
\end{abstract}

Keywords: Student Perception, Field Lecture, Vertebrate Zoology

\begin{abstract}
ABSTRAK
Tujuan penelitian ini adalah untuk memperoleh gambaran tentang persepsi mahasiswa terhadap kegiatan praktik lapangan zoologi vertebrata yang berupa kunjungan ke LIPI Cibinong. Metode penelitian yang digunakan adalah metode deksriptif dengan menggunakan teknik survey. Survey dilakukan terhadap 52 mahasiswa tingkat akhir Program Studi Pendidikan Biologi UIN SGD Bandung. Hasil penelitian menunjukkan bahwa 80,2 \% Mahasiswa memberikan persepsi positif terhadap program kuliah lapangan zoologi vertebrata, karena mahasiswa menilai program kuliah lapangan ini dapat meningkatkan kebermaknaan proses pembelajaran, memperluas wawasan mengenai materi zoologi vertebrata, dapat mempererat keakraban antar mahasiswa. Selain itu mahasiswa memandang bahwa kuliah lapangan ini sebagai salah satu implementasi kegiatan Edutainment.
\end{abstract}

Kata Kunci : Persepsi Mahasiswa, Kuliah Lapangan, Zoologi Vertebrata

\section{PENDAHULUAN}

Proses pembelajaran merupakan aktivitas yang kompleks, bukan hanya transfer of knowledge dari pendidik kepada peserta didik, akan tetapi merupakan proses yang bertujuan untuk mengantarkan peserta didik pada penguasaan kompetensi yang dicanangkan, termasuk nilai-nilai dan sikap yang melandasinya. Oleh karena itu pembelajaran tidak harus selalu 
dilaksanakan di kelas, seringkali pembelajaran harus dilaksanakan di laboratorium atau di lapangan (Direktorat Tenaga Kependidikan Direktorat Jenderal Peningkatan Mutu Pendidik Dan Tenaga Kependidikan Departemen Pendidikan Nasional, 2008). Patrick (2010) mengungkapkan bahwa pembelajaran biologi dapat dilakukan dengan dua cara yaitu melalui praktikum di laboratorium dan melalui studi lapangan (field study).

Studi lapangan berkaitan dengan kegiatan peserta didik yang dilakukan di lingkungan belajar di luar kelas tradisional (konvensional), seperti lingkungan kantor, area bersejarah, monumen dan museum, taman nasional, kebun binatang, lahan basah, tepi laut, area kehidupan liar, dll yang bertujuan untuk mencapai tujuan instruksional tertentu (Vassala, 2006; Sumaatmadja, 1984). Lebih jauh Vassala (2006) mengungkapkan bahwa studi lapangan memungkinkan peseta didik berpastisipasi dalam proses pembelajaran sehingga membantu mereka untuk mendapatkan pengetahuan pengetahuan, pengalaman, dan keterampilan baru. Dengan kata lain, studi lapangan berkontribusi dalam memberikan perubahan positif pada peserta didik melalui pembelajaran yang terjadi pada tingkat pengetahuan, keterampilan dan sikap (Hudak, 2003; Vassala, 2006; Patrick, 2010; Nedelson \& Jordan, 2012). Hasil penelitian membuktikan pentingnya studi lapangan dalam memberikan pengalaman nyata atau otentik kepada peserta didik dalam pembelajaran sains, dapat kontak langsung dengan benda nyata, dan dapat menstimulasi rasa ingin tahu (Ibrahim dkk, 2016). Dari rasa ingin tahun inilah yang akan mengantarkan kepada penemuan sains (Fleischneret al, 2017).

Kegiatan pembelajaran seperti ini termasuk cara mencerdaskan, mendewasakan, dan membebaskan peserta didik dalam mengembangkan pemikiran (Learning to think), menambah pengalaman mengajar (Learning by expirience), menimbulkan rasa peduli (Learning to care), dan rasa tanggung jawab terhadap masyarakat sekitarnya (Learning to live together) (Onah, 2008). Menurut Hadisubroto (2001) studi lapangan dengan pengalaman langsung mengharuskan peserta didik belajar menggunakan proses-proses IPA, dimulai dari mengamati, mengklasifikasi, memprediksi, mengukur, berkomunikasi, menginterpretasikan data, menyusun defenisi operasional, menyusun pertanyaan dan hipotesis, eksperimentasi, memformulasikan model-model, menilai dan menyimpulkan. Pentingnya studi lapangan juga disampaikan oleh Fleischneret al (2017) yang mengungkapkan bahwa studi lapangan mendorong peserta didik untuk mengamati alam (mengekstraksi pemahaman), bercakap-cakap dengan alam (mengembangkan empati), dan berpartisipasi dalam alam (menggunakan sumber daya). Sementara Nabros et al (2009) mengungkapkan bahwa studi lapangan mampu mempertajam kemampuan dalam melakukan 
observasi dan persepsi dengan menggunakan berbagai alat indera yang dimiliki peserta didik. Pendidikan berbasis lapangan sangat penting untuk ilmu biologi karena memberikan pelatihan dasar untuk disiplin ilmu utama seperti biologi perilaku, ekologi, evolusi, sistematika, dan ilmu konservasi (Fleschner et al, 2017).

Zoologi Vertebrata merupakan mata kuliah yang diberikan kepada mahasiswa calon guru biologi yang dalam proses pembelajarannnya tidak hanya di ruang kelas atau di laboratorium tetapi juga dengan melaksanakan studi lapangan. Tujuan dari kegiatan studi lapangan dalan mata kuliah zoologi vertebrata adalah memberikan pengalaman langsung kepada mahasiswa calon guru biologi untuk mengenal keanekaragaman jenis hewan yang ada di Indonesia atau pun di dunia. Sebagaimana kita ketahui bahwa Indonesia merupakan negara dengan keanekaragaman hayati yang tinggi. Berdasarkan data yang dikeluarkan oleh BAPPENAS (2016) Indonesia tercatat memiliki 720 jenis mamalia (13\% jumlah jenis dunia), 1.605 jenis burung (16\% jumlah jenis dunia), Reptilia 723 jenis ( $8 \%$ dari jumlah jenis dunia), 385 jenis amphibia (6\% dari jumlah jenis dunia), 1.248 jenis ikan air tawar (9\% dari jumlah jenis dunia) dan 3.476 jenis ikan laut. Lebih jauh BAPPENAS (2016) juga melaporkan dari sekian banyak jenis vertebrata yang ada di Indonesia banyak hewan vertebrata yang merupakan vertebrata endemis Indonesia, yaitu 270 jenis mamalia, 386 jenis burung, 328 jenis reptil, dan 204 jenis amphibia. Mengingat keanekaragaman jenis hewan vertebrata Indonesia yang tinggi, maka penting bagi mahasiswa calon guru biologi untuk mengenal dan mempelajari perikehidupan hewan vertebrata. Salah satu metode untuk mengenalkan keanekaragaman hewan vertebrata adalah dengan melakukan studi lapangan dengan mengunjungi Lembaga Ilmu Pengetahuan Indonesia (LIPI).

Bidang Zoologi, Pusat Penelitian Biologi, Lembaga Ilmu Pengetahuan Indonesia, merupakan lembaga yang mempelopori penelitian dalam keilmuan fauna. Lembaga ini dulu dikenal dengan nama Museum Zoologicum Bogoriense (MZB) yang didirikan oleh J.C. Koningsberger pada bulan Agustus 1894. Sejak berdirinya sampai dengan tahun 1997, Bidang Zoologi menempati gedung bersejarah di dalam Kebun Raya Bogor, yang secara ilmiah merupakan kebun raya terkenal di dunia. Di dalamnya termasuk pameran umum, yang menyajikan keanekaragaman fauna Indonesia. Sejalan dengan perkembangan ilmu agar kegiatan penelitian dapat ditampung, maka Bidang Zoologi pindah dan menempati gedung baru di Pusat Ilmu Pengetahuan Cibinong (Cibinong Science Centre). Gedung yang diberi nama Widyasatwaloka ini dibangun dengan bantuan dana dari Pemerintah Jepang pada tahun 1997. Sedangkan fasilitas penyimpanan koleksi diadakan dengan bantuan dana GEF/Word Bank dalam rangka peningkatan kualitas dan pengelolaan koleksi ilmiah 
specimen bertaraf internasional. Dengan melakukan kunjungan ke LIPI pada bidang zologi diharapkan mahasiswa Pendidikan Biologi UIN Sunan Gunung Djati Bandung mendapatkan informasi yang sebanyak banyaknya mengenai khasanah keragaman binatang yang ada di Indonesia serta memberikan pengalaman langsung kepada mahasiswa untuk mengamati dan mengobservasi ke lapangan terkait hewan-hewan bertulang belakang (vertebrata) untuk dapat diidentifikasi maupun dideskripsikan sehingga antara kuliah teori yang didapatkan selama perkuliahan sejalan dengan contoh asli yang di dapat di lapangan. Mengingat pentingnya kedudukan kuliah lapangan bagi mahasiswa calon guru biologi, maka dipandang perlu untuk meneliti persepsi mahasiswa calon guru biologi dalam melaksanaan kuliah lapangan zoologi vertebrata. Berdasarkan pernyataan tersebut maka Penelitian ini bertujuan untuk mendapatkan gambaran tentang persepsi mahasiswa terhadap kegiatan praktik lapangan zoologi vertebrata berupa kunjungan ke LIPI Cibinong yang dilaksanakan pada program studi pendidikan biologi FTK UIN SGD Bandung pada bulan April 2017.

Persepsi menurut Slamento (1995) adalah proses masuknya informasi ke dalam otak manusia dan menterjemahkannya. Sobur (2003) menyatakan bahwa persepsi adalah proses menerima, menyeleksi, mengorganisasikan, mengartikan, menguji dan memberikan respon terhadap rangsangan pancaindera. Sementara Walgito (2010) medefinisikan persepsi sebagai suatu proses penginderaan yang diawali dari adanya stimulus yang diterima kemudian diorganisasikan dan diinterpertasikan. Dengan demikian, persepsi mahasiswaadalah suatu pandangan atau proses penerimaan, pengorganisasian, penginterpretasian mahasiswa yang dalam penelitian di sini adalah tentang pandangan mereka terhadap pelaksanaan praktek kuliah lapangan pada mata kuliah zoologi vertebrata. Persepsi akan mempengaruhi tindakan, baik persepsi baik maupun persepsi buruk. Tindakan positif biasanya muncul apabila kita mempersepsi seseorang secara positif dan sebaliknya (Sugihartono dkk, 2007). Oleh karena itu, penting untuk mengetahui persepsi mahasiswa terhadap pelaksanaan praktek kuliah lapangan zoologi vertebrata.

\section{METODOLOGI PENELITIAN}

Metode penelitian yang digunakan dalam penelitian ini metode deksriptif dengan menggunakan teknik survey. Survey dilakukan terhadap 52 mahasiswa Program Studi Pendidikan Biologi FTK UIN Sunan Gunung Jati Bandung yang mengambil kuliah lapangan zoologi vertebrata pada tahun 2017. Instrument yang digunakan dalam penelitian ini berupa angket persepsi mahasiswa terhadap pelaksanaan kuliah lapangan yang dikembangkan oleh peneliti. Adapun Teknik Pengumpulan Data yang dilakukan dijelaskan sebagai berikut: 


\section{A. Observasi langsung}

Melakukan Observasi langsung ke pelaksanaan kuliah lapangan zoologi vertebrata yang dilaksanakan pada tahun 2017. Observasi dilakukan pada saat persiapan berlangsung di kampus hingga pelaksanaan dilapangan. Observasi ini dilakukan untuk menggali informasi segala hal mengenai persiapan belajar mahasiswa calon guru biologi hingga evaluasi pelaksanaan kuliah lapangan yang telah dilaksanakan.

B. Angket

Angket yang disebar kepada mahasiswa adalah Angket untuk menjaring respon/tanggapan mengenai persepsi mahasiswa calon guru biologi dalam mengikuti perkuliahan lapangan zoologi vertebrata ke LIPI Cibinong Tahun 2017. Angket ini difokuskan pada pengungkapan persepsi mahasiswa terhadap pelaksanaan perkuliahan lapangan zoologi vertebrata Pendidikan Biologi FTK UIN SGD Bandung. Adapun angket disebar melalui jejaring online dengan Alamat :

https://forms.office.com/Pages/ResponsePage.aspx?id=oBaJUIl7oUOvTnLFaulufqEdRno

\section{Hg9IuCbNR-gJP35UNFIPM0INTjNaVkxEMU5ROVZGOFVENjlMQy4u}

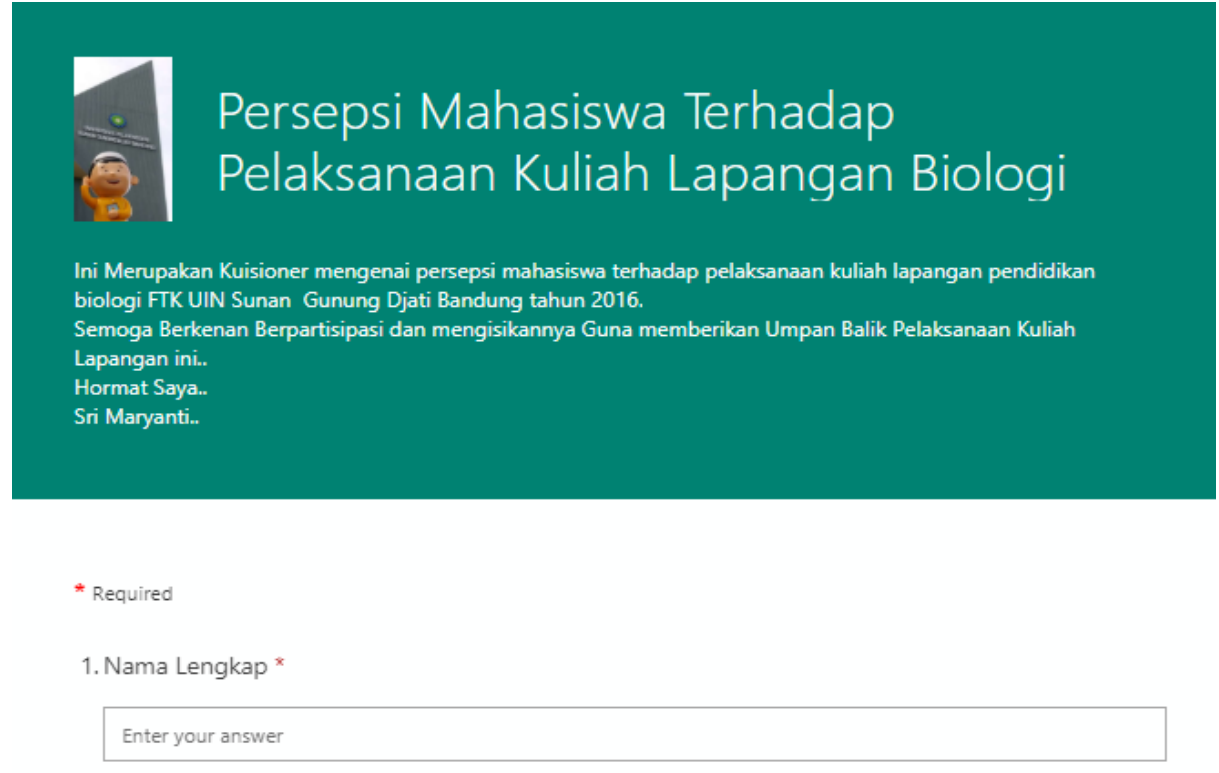

2. Nomor Induk Mahasiswa *

Enter your answer

Gambar 1. Angket Penelitian Yang dikembangkan Oleh Peneliti Untuk Mengungkap Persepsi Mahasiswa Calon Guru Biologi terhadap Pelaksanaan Kuliah Lapangan Zoologi

C. Wawancara Vertebrata

Wawancara dilakukan dengan dosen yang bertujuan untuk mengetahui arahan tugas yang digunakan dalam pelaksanaan kuliah lapangan zoologi vertebrata, hambatan yang 
dihadapi dosen/mahasiswa dalam menjalankan perkuliahan lapangan. Selain itu, wawancara dilakukan kepada beberapa mahasiswa calon guru biologi untuk mengetahui Persepsi/Motivasi belajar lainya yang kurang terungkap melalui angket.

Secara umum, kegiatan penelitian ini dapat dilihat pada alur penelitian di bawah ini :

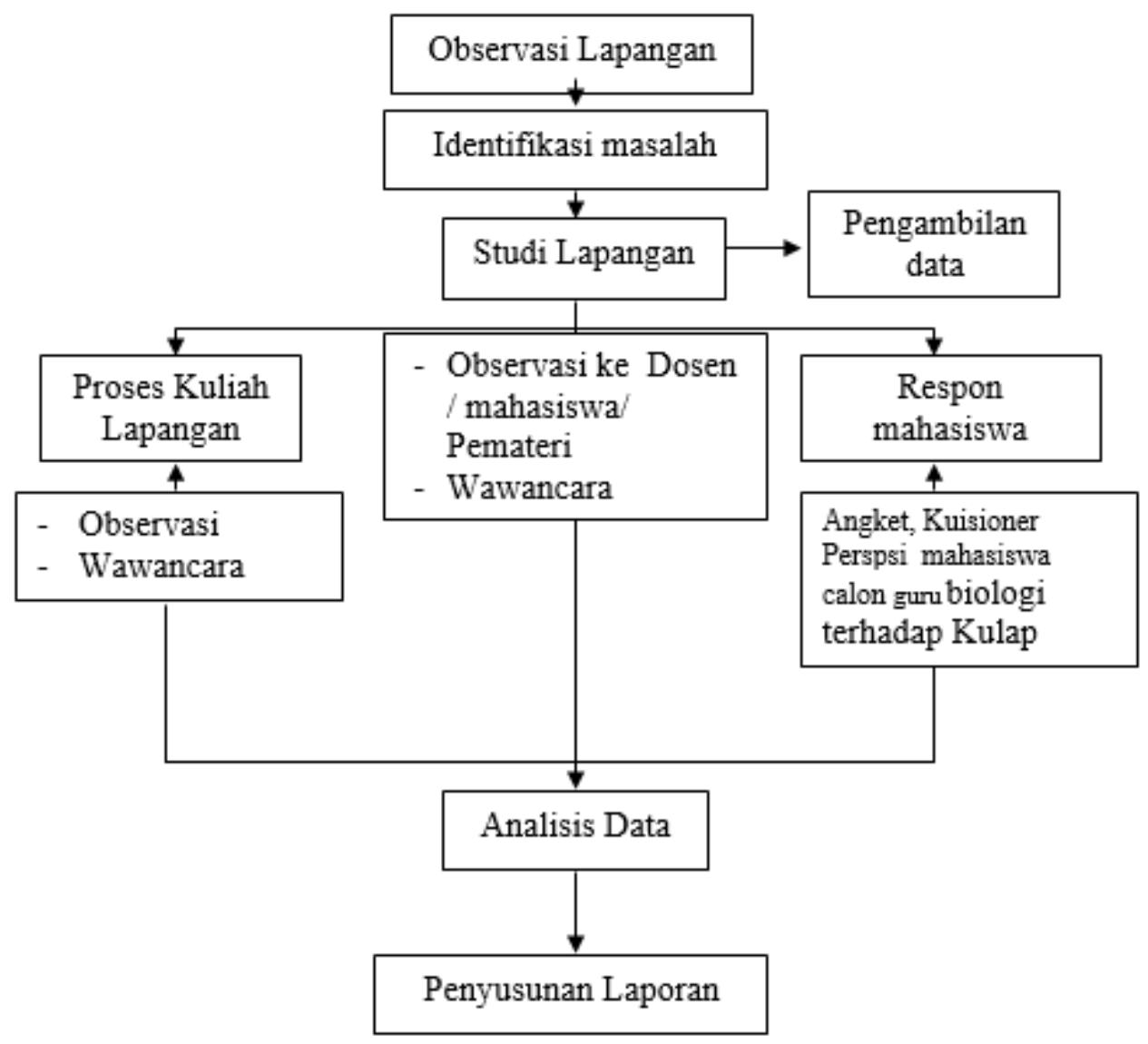

\section{Gambar 1. Alur Penelitian}

\section{HASIL DAN PEMBAHASAN}

Kegiatan kuliah praktek lapangan ini dilaksanakan satu hari pada tanggal 20 April 2017. Selama 2-3 jam mahasiswa diberikan informasi mengenai sejarah dan aktivitas yang dilakukan oleh Bidang Zoologi, Pusat Penelitian Biologi LIPI Cibinong melalui bahan tayang power point secara klasikal didalam auditorium dan mahasiswa diberikan kesempatan pada sesi tanya jawab untuk bertanya terkait itu. Setelah sesi klasikal di auditorium mahasiswa dikondisikan untuk dibentuk menjadi beberapa kelompok kerja, yang masing-masing kelompok akan mengunjungi beberapa laboratorium atau ruang koleksi. Fokus kunjungan kami yaitu pada laboratorium biosistematika yang terdiri dari laboratorium :Burung, Reptil \& Amphibi, mamalia serta laboratorium invertebrate. Masing-masing laboratorium ada penanggung jawab yang bersiap untuk menjelaskan dan mendeskripsikan 
apa yang ada atau berkaitan dengan laboratorium dan seisinya sehingga mahasiswa pada masing-masing lab berkewajiban untuk menyimak, memperhatikan maupun mencatat serta mendokumentasikan apa yang mereka dapatkan sebagai hasil kunjungan untuk kemudian dideskripsikan.

Museum Zoologi Bogor adalah museum yang terletak di Bogor, memiliki koleksi yang berkaitan dengan dunia satwa seperti berbagai spesimen yang diawetkan maupun fosil hewan. Museum ini terbagi menjadi dua, salah satunya dibuka setiap hari untuk umum yang berisi ruang pameran terletak di Jalan Ir. H. Juanda No. 9 Bogor, atau tepatnya berada di dalam Kebun Raya Bogor. Museum yang satu lagi berfungsi sebagai tempat koleksi dan hanya dibuka untuk umum setahun sekali pada bulan Oktober, berada di Pusat Ilmu Pengetahuan Cibinong tepatnya di Jalan Raya Jakarta - Bogor Km.46 Cibinong, Bogor. Kedua bagian museum ini dikelola oleh Bidang Zoologi Pusat Penelitian Biologi-LIPI.

Koleksi Museum Zoologi yang berada di gedung Widyasatwaloka, Pusat Ilmu Pengetahuan Cibinong meliputi 3,5\% jumlah jenis fauna yang terdapat di Indonesia, dan dari keberagaman fauna di Indonesia hanya $0,05 \%$ contoh binatang (spesimen) yang dimiliki oleh Bidang Zoologi, Pusat Penelitian Biologi, LIPI. Koleksi ilmiah untuk kepentingan penelitian meliputi beberapa kelompok sebagai berikut: Mamalia, Ikan, Burung, Reptil dan Amfibia, Moluska, Serangga dan Invertebrata.

Hasil kegiatan kuliah lapangan harus dirangkum dan dibuatkan laporan sesuai dengan yang telah ditugaskan sebelumnya. Pada pada dasarnya kegiatan kuliah lapangan yang dilakukan berhasil dari segi pelaksanaan dan hasil yang diperoleh. Kegiatan kuliah lapangan Zoologi ini dilaksanakan dengan agenda mengamati, mengobservasi serta mengidentifikasi secara langsung pada objek sebenarnya sehingga memberikan mahasiswa pengalaman belajar di luar perkuliahan yang berkesan. Pengalaman belajar yang baik dapat menciptakan proses pembelajaran menjadi lebih inovatif. 


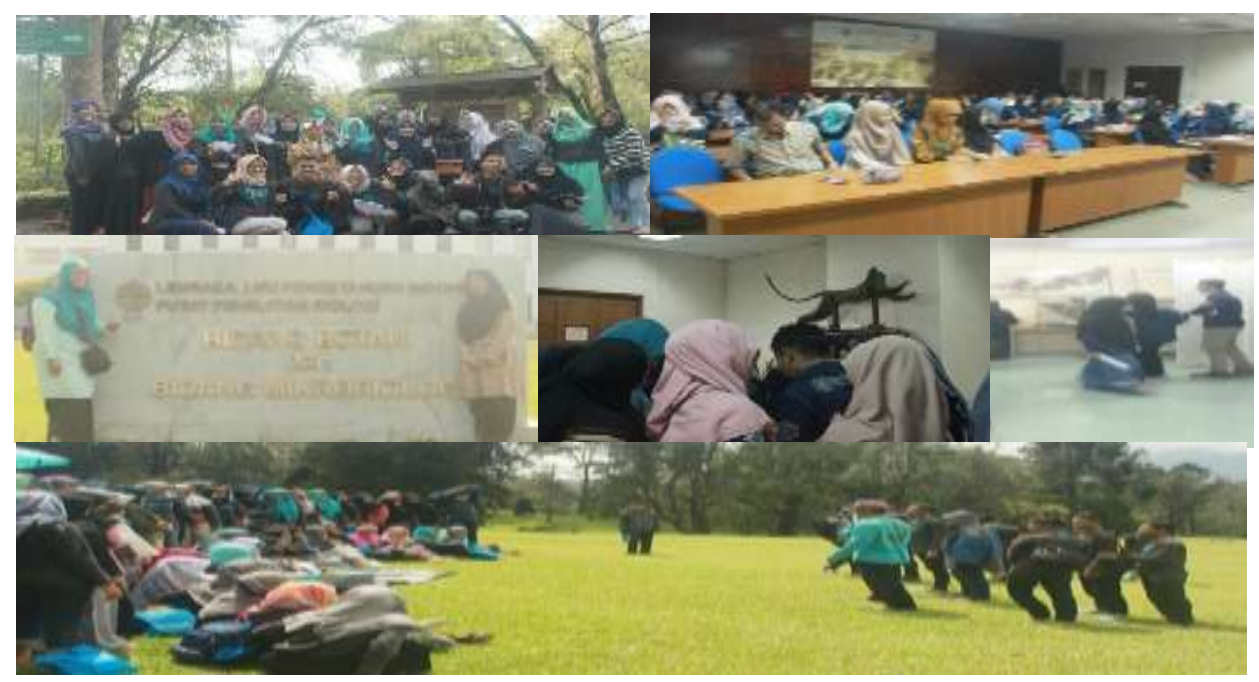

Gambar 2. Dokumentasi Pelaksanaan Kuliah Lapangan lapangan zoologi vertebrata berupa kunjungan ke LIPI Cibinong yang dilaksanakan pada program studi pendidikan biologi FTK UIN SGD Bandung pada bulan April 2017

Hasil penelitian yang diperoleh dalam penelitian ini berupa persepsi mahasiswa terhadap pelaksanaan kuliah lapangan yang dilakukan pada Program Studi Pendidikan Biologi FTK UIN SGD Bandung.Data persepsi mahasiswa terhadap pelaksanaan kuliah lapangan dapat dilihat pada Tabel 1di bawah ini.

Tabel 1. Persepsi mahasiswa calon guru biologi terhadap perkuliahan lapangan yang telah dilakukan

\begin{tabular}{|l|l|l|}
\hline No & \multicolumn{1}{|c|}{ Pertanyaan } & \multicolumn{1}{c|}{ Kuantitas / Deskripsi Jawaban } \\
\hline 1 & $\begin{array}{l}\text { Apakah kegiatan kuliah } \\
\text { lapangan merupakan } \\
\text { kegiatan yang } \\
\text { menyenangkan? }\end{array}$ & $\begin{array}{l}\text { 98\% menjawab Iya. } \\
\text { Dengan Rincian Jawaban Karena dengan kuliah } \\
\text { lapangan kita dapat bermain sambil belajar, disamping } \\
\text { itu apa yang kita amati ini dalam bentuk real bukan } \\
\text { hanya sekedar gambar jadi lebih mudah. } \\
\text { Karena selain mendapatkan pengetahuan dan } \\
\text { pengalaman, sekalian refreshing }\end{array}$ \\
\hline 2 & $\begin{array}{l}\text { Apakah kegiatan Kuliah } \\
\text { lapangan dapat } \\
\text { menambah wawasan? }\end{array}$ & $\begin{array}{l}\text { 100\% Menjawab iya } \\
\text { Dengan Rincian Jawaban Karena menemukan spesies } \\
\text { baru, cara mengawetkan, dan ilmu lainnya, } \\
\text { pembelajaran dan pengamatan langsung aspek yg d } \\
\text { capai dan diamati lebih mengena dan luas, terbukti } \\
\text { dengan satu materi di kelas bisa dijabarkan dengan } \\
\text { pembuktian di lapangan }\end{array}$ \\
\hline
\end{tabular}




\begin{tabular}{|c|c|c|}
\hline No & Pertanyaan & Kuantitas / Deskripsi Jawaban \\
\hline 3 & $\begin{array}{l}\text { Apakah kegiatan kuliah } \\
\text { lapangan yang selama ini } \\
\text { dilakukan sudah efektif? }\end{array}$ & $\begin{array}{l}52 \% \text { menjawab Efektif. } \\
\text { Dengan rincian karena kurangnya tenaga pembimbing } \\
\text { pada saat kuliah lapangan berlangsung sehingga hanya } \\
\text { beberapa orang yang memperhatikan pada saat } \\
\text { pembimbing menjelaskan. Karena penjelajarahan yang } \\
\text { dilakukan belum bebas hanya sebatas apa yg ada d sana } \\
\text { itupun hanya sebagian yang dapat di identifikasi } \\
\text { karena waktu yang terbatas juga. }\end{array}$ \\
\hline 4 & $\begin{array}{l}\text { Apakah kuliah lapangan } \\
\text { yang selama ini dilakukan } \\
\text { dapat memacu rasa ingin } \\
\text { tahu untuk menggali } \\
\text { informasi lebih dalam } \\
\text { lagi? }\end{array}$ & $\begin{array}{l}98 \% \text { menjawab iya } \\
\text { Dengan rincian secara tidak langsung mahasiswa harus } \\
\text { mencari sumber yang lebih lengkap untuk pembuatan } \\
\text { laporan sehingga mau tidak mau mahasiswa harus } \\
\text { membaca terlebih dahulu, dengan pengalaman kuliah } \\
\text { lapangan ketika berada disuatu lingkungan baru dan } \\
\text { melihat beberapa jenis tanaman yang belum pernah } \\
\text { diidentifikasi menjadi timbul rasa ingin tahu dan } \\
\text { mengidentifikasinya. }\end{array}$ \\
\hline 5 & $\begin{array}{l}\text { Apakah kuliah lapangan } \\
\text { yang selama ini dilakukan } \\
\text { melatihkan kemampuan } \\
\text { metode ilmiah termasuk } \\
\text { pemecahan masalah? }\end{array}$ & $\begin{array}{l}71 \% \text { menjawab iya } \\
\text { Dengan rincian Terdapat beberapa hal yang muncul } \\
\text { ketika kita melihat suatu gambar atau pun deskripsi } \\
\text { tentang suatu hal, dengan adanya kuliah lapangan ini } \\
\text { beberapa permasalahan tersebut dapat terpecahkan } \\
\text { atau setidaknya hipotesis mengenai suatu hal tersebut } \\
\text { dapat kita teliti kembali hingga menghasilkan suatu } \\
\text { kesimpulan }\end{array}$ \\
\hline 6 & $\begin{array}{l}\text { Apakah kuliah lapangan } \\
\text { yang selama ini dilakukan } \\
\text { melatihkan kemampuan } \\
\text { berfikir kritis? }\end{array}$ & $\begin{array}{l}88 \% \text { menjawab iya } \\
\text { Dengan rincian melihat secara langsung objek akan } \\
\text { timbul banyak pertanyaan, misalnya kenapa warna } \\
\text { bunga tumbuhan A dengan tumbuhan B bisa berbeda } \\
\text { padahal secara morfologi batang, daun dan sebagainya } \\
\text { sama. Hal itu akan membuat kita semakin berfikir } \\
\text { sehingga menimbulkan banyak pertanyaan. }\end{array}$ \\
\hline
\end{tabular}




\begin{tabular}{|c|c|c|}
\hline No & Pertanyaan & Kuantitas / Deskripsi Jawaban \\
\hline 7 & $\begin{array}{l}\text { Apakah kuliah lapangan } \\
\text { yang selama ini dilakukan } \\
\text { melatihkan kemampuan } \\
\text { berinkuiri? }\end{array}$ & $\begin{array}{l}81 \% \text { menjawab iya } \\
\text { Dengan rincian karena mahasiswa dituntut untuk } \\
\text { banyak bertanya mengenai objek yang diamati } \\
\text { kemudian ia bisa memberikan hipotesis dari apa yang } \\
\text { ia amati di lingkungan tempat ia mengamati objek } \\
\text { tersebut }\end{array}$ \\
\hline 8 & $\begin{array}{l}\text { Apakah program kuliah } \\
\text { lapangan yang selama ini } \\
\text { dilakukan melatihkan } \\
\text { kemampuan pemecahan } \\
\text { masalah? }\end{array}$ & $\begin{array}{l}83 \% \text { menjawab iya } \\
\text { Dengan rincian seperti pada matkul botani } \\
\text { phanerogamae yg pencarian spesiesnya cukup sulit dan } \\
\text { kebanyakan pada saat praktikum hanya menggunakan } \\
\text { gambar tanpa melihat objek secara langsung maka } \\
\text { dengan adanya kuliah lapangan dapat membantu untuk } \\
\text { mengetahui objek2 secara langsung }\end{array}$ \\
\hline 9 & $\begin{array}{l}\text { Apakah Lembar Kerja } \\
\text { Mahasiswa dapat } \\
\text { membantu kegiatan kuliah } \\
\text { lapangan? }\end{array}$ & $\begin{array}{l}96 \% \text { menjawab iya } \\
\text { Dengan rincian Karena dengan adanya lembar kerja } \\
\text { kita lebih terpandu mudah untuk melaksanakan } \\
\text { identifikasi di lapangan, dengan adanya lembar kerja, } \\
\text { mahasiswa tidak bingung dengan apa yang harus } \\
\text { dikerjakan pada saat kukiah lapangan berlangsung }\end{array}$ \\
\hline 10 & $\begin{array}{l}\text { Apakah Kuliah Lapangan } \\
\text { Melatihkan Aspek } \\
\text { Kognitif, Psikomotor dan } \\
\text { Afketif? }\end{array}$ & $\begin{array}{l}94 \% \text { menjawab iya } \\
\text { Dengan rincian dari aspek kognitif kita dituntut untuk } \\
\text { mengetahui apa yang diteliti dan meningkatkan } \\
\text { keingintahuan mahasiswa terhadap objek objek } \\
\text { tertentu, untuk ranah afektif mahasiswa dituntut untuk } \\
\text { memiliki sikap yang baik terhadap sesama makhluk } \\
\text { hidup, untuk ranah psikomotorik mahasiswa dituntut } \\
\text { untuk mampu mendayagunakan kemampuannya untuk } \\
\text { menjaga kelestarian objek kajian Biologi }\end{array}$ \\
\hline 11 & $\begin{array}{l}\text { Apakah program kuliah } \\
\text { lapangan harus tetap ada } \\
\text { di prodi Pendidikan } \\
\text { biologi? }\end{array}$ & $\begin{array}{l}90 \% \text { menjawab iya } \\
\text { Dengan rincian Karena selain membuat antar peserta } \\
\text { lebih akrab, dosen dan mahasiswa akrab, kita juga } \\
\text { dapat menemukan hal hal baru yang tidak ditemukan }\end{array}$ \\
\hline
\end{tabular}




\begin{tabular}{|l|l|l|}
\hline No & \multicolumn{1}{|c|}{ Pertanyaan } & \multicolumn{1}{c|}{ Kuantitas / Deskripsi Jawaban } \\
\hline 12 & $\begin{array}{l}\text { Bagaimana Peran Dosen } \\
\text { Pembimbing Dalam } \\
\text { disampaikan dikelas, belajar menghargai orang lain }\end{array}$ \\
$\begin{array}{l}\text { Pelaksanaan Kuliah } \\
\text { Lapangan? }\end{array}$ & $\begin{array}{l}\text { Dengan rincian Dosen pembimbing sangat membantu } \\
\text { pada saat pelaksanaan karena dengan adanya dosen } \\
\text { pembimbing kita bisa bertanya apapun yang belum kita } \\
\text { ketahui }\end{array}$ \\
\hline $\begin{array}{l}\text { Rating Pelaksanaan } \\
\text { Kuliah Lapangan Kali } \\
\text { Kurang baik, Bintang 5 } \\
\text { Untuk Sangat Baik }\end{array}$ & $\begin{array}{l}\text { Didapat Rata-rata 4.02 dari Skala Maksimum 5 } \\
\text { Dengan rincian Kuliah lapangan ini dapat } \\
\text { dimaksimalkan untuk penambahan wawasan baru } \\
\text { ataupun mengingat kembali materi yang telah } \\
\text { dijelaskan di kelas, selain itu dapat mempererat tali } \\
\text { persaudaraan dengan teman angkatan }\end{array}$ \\
\hline
\end{tabular}

Dari data yang didapatkan diketahui bahwa 80,2 \% Mahasiswa memberikan persepsi positif terhadap program kuliah lapangan zoologi vertebrata, karena mahasiswa menilai program kuliah lapangan ini dapat meningkatkan kebermaknaan proses pembelajaran, memperluas wawasan mengenai konten biologi di zoologi vertebrata dan dapat mempererat keakraban antar mahasiswa yang menganggap bahwa kuliah lapangan ini sebagai salah satu implementasi kegiatan Edutaiment.

Berdasarkan data angket pada Tabel 1 di atas terlihat $100 \%$ mahasiswa memandang bahwa kuliah lapangan dapat menambah wawasan dan pengetahuan, 94\% dapat melatih aspek kognitif, apektif dan psikomotorik dan $98 \%$ merangsang rasa ingin tahu. Hal ini sejalan dengan pendapat Patrick (2010) yang menyatakan bahwa pelaksanaan studi lapangan dapat memberikan kesempatan kepada mahasiswa untuk menambah pengetahuan. Penelitian Hutson (2011) menunjukkan bahwa mahasiswa menyakini pelaksanaan studi lapangan dapat meningkatkan pengetahuan mereka. Vassala (2006) mengemukakan bahwa studi lapangan adalah teknik pendidikan, yang membuat proses pendidikan lebih aktif, membantu siswa untuk bekerja dalam situasi nyata dan untuk mengembangkan keterampilan, kompetensi dan sikap positif. Bukti menunjukkan bahwa pelaksanaan kuliah lapangan berkontribusi pada peningkatan kinerja akademik dankognitif pada mahasiswa biologi (Easton dan Gilburn 2012). Demikian juga hasil penelitian Ibrahim dkk (2017) menunjukkan bahwa pelaksanaan 
kuliah lapangan dapat meningkatkan penguasaan konsep mahasiswa. Hal ini dimungkinkan terjadi karena dengan studi lapangan mahasiswa memiliki kesempatan lebih besar untuk memupuk koneksi kritis ke tempat nyata yang mengubah konsep abstrak menjadi realitas nyata (Fleschner et al, 2017).NRC (2009) mengemukakan bahwa peserta didik yang mendapatkan pengalaman belajar autentik akan mengembangkan rasa ingin tahu siswa dan minat siswa serta mendorong siswa untuk mempelajari sesuatu lebih dalam.

Berdasarkan data angket Tabel 1 juga diketahui bahwa mahasiswa memandang kuliah lapangan dapat mempererat keakraban antarmahasiswa maupun mahasiswa dengan dosen. Hal ini pun sejalan dengan dengan pendapat Barker et al (2002) yang menyatakan bahwa studi lapangan merupakan kegiatan yang penting dalam pembelajaran biologi karena melalui studi lapangan peserta didik dilatih untuk bekerja dalam tim, dan memberikan kesempatan bagi guru untuk mengembangkan hubungan yang berbeda, berpotensi lebih positif dan produktif dengan peserta didik mereka. Studi lapangan juga sering melibatkan peserta didik bekerja bersama dengan teman sebaya. Dinamika dan hubungan timbal balik yang dikembangkan saat bekerja dalam kelompok dapat memiliki pengaruh besar pada bagaimana peserta didik berkembang secara sosial.

Pelaksanaan kuliah lapangan dapat memenuhi ekspektasi semua pihak. Secara akademik terpenuhi, secara rekreasi juga terpenuhi. Bila program pembelajaran berjalan secara baik dan peserta didik merasa senang, maka hasil pembelajaran diharapkan baik dan bermakna. Keberhasilan kuliah lapangan terjadi karena mahasiswa memahami tujuan dan manfaat dari kegiatan lapangan. Dengan memahami tujuan, mahasiswa tahu apa yang harus dilakukan. Dengan memahami manfaat, mahasiswa termotivasi untuk menyelesaikan program yang ada dalam kuliah lapangan.

Keberhasilan kuliah lapangan juga diantaranya karena ditunjang oleh instrumen/panduan/lembar kerja lapangan yang mudah dimengerti oleh mahasiswa. Perintah-perintahnya jelas dan dapat dilaksanakan oleh mahasiswa. Isi dari lembar kerja mahasiswa yang lengkap juga memudahkan mahasiswa melaksanakan program-program kuliah lapangan. Disamping itu peran dosen pembimbing juga memiliki peran penting dalam kesuksesan pelaksanaan kuliah lapangan yang dilaksanakan. 


\section{SIMPULAN}

Mahasiswa memberikan persepsi positif terhadap program kuliah lapangan zoologi vertebrata, karena mahasiswa menilai program kuliah lapangan ini dapat meningkatkan kebermaknaan proses pembelajaran, memperluas wawasan mengenai materi zoologi vertebrata, dapat mempererat keakraban antar mahasiswa. Selain itu mahasiswa memandang bahwa kuliah lapangan ini sebagai salah satu implementasi kegiatan Edutainment.

\section{DAFTAR PUSTAKA}

Abidin, Z. (2017). Evaluasi Program Kuliah Lapangan Ekologi Hewan Pada Sebuah Universitas Swasta Di Kabupaten Kuningan Jawa Barat. Quangga, 09 (02),1-9.

BAPPENAS (2016). Indonesian Biodiversity Strategy and Action Plan(IBSAP) 2015-2020. Kementrian Perencanaan Pembangunan.

Barker, S.S., D.Tilling, S. (2002). Teaching Biology outside classroom is it heading for extinction. Field Studies Council and the British Ecological Society.

Direktorat Tenaga Kependidikan Direktorat Jenderal Peningkatan Mutu Pendidik Dan Tenaga Kependidikan Departemen Pendidikan Nasional. (2008). Proses Pembelajaran Di Kelas, Laboratorium, Dan Di Lapangan.

Easton E, Gilburn A. (2012). The field course effect: Gains in cognitive learning in undergraduate biology students following a field course. Journal of Biological Education, $46,29-35$.

Fleischner, L. Thomas. Robert E. Espinoza, Gretchen A. Gerrish, Harry W. Greene, Robin Wall Kimmerer, Eileen A. Lacey, Steven Pace, Julia K. Parrish, Hilary M. Swain, Stephen C. Trombulak, Saul Weisberg, David W. Winkler, And Lisa Zande. (2017), Teaching Biology in the Field: Importance, Challenges, and Solutions. BioScience 67: 558-567.

Hadisubroto, T., (2001), Meningkatkan Keterampilan Guru Dalam PembelajaranIPA Kelas III SD Melalui Pengalaman Langsung, Jurnal Ilmu Pendidikan,8 (2): 161-170.

Hudak, P. (2003). Campus field exercises for introductory geoscience courses. Journal of Geography, 102(5): 220-225.

Hutson, T., Cooper, S., \& Talbert, T. (2011). Describing connections between science content and future careers: Implementing Texas curriculum for rural at-risk high school students using purposefully-designed field trips. Rural Educator, 31, 37-47.

Ibrahim, Y.R., Hertien K.S. (2016). Persepsi Mahasiswa Terhadap Pengembangan Program Kuliah Lapangan Terpadu (Integrated Field Trip). Biosfer, J.Bio. \& Pend.Bio, 1(1), 43 47. 
Ibrahim, Y.R., Hertien K.Surtikanti. (2017). Kuliah Lapangan Terpadu Berbasis Inkuiri untuk Meningkatkan Penguasaan Konsep Mahasiswa Pendidikan Biologi. Biosfer, J.Bio. \& Pend.Bio, 2(2), 1-5.

Nabors, M.L., Edwards, L.C., \& Murray, R.K. (2009). Making the case for field trips:What research tells us and what site coordinators have to say. Education, 129(4), 661-667.

Nadelson, L., \& Jordan, J. (2012). Student attitudes toward and recall of outside day: An environmental science field trip. Journal of Educational Research, 105(3), 220-231.

NRC (National Research Council.) (2009). Learning science in informal environments: People, places, and pursuits. Washington, DC: The National Academies Press.

Onah. (2008). Pengaruh Penggunaan Metode Kuliah Lapangan (Field Trip)Terhadap Hasil Belajar Mata Kuliah Taksonomi Tingkat Rendah, Skripsi,Universitas Islam Negeri Syarif Hidayatullah, Jakarta.

Patrick, A.O. (2010). Effect of Field Study on Learning Outcome in Biology, J.Hum Ecol.,31/33:171-177.

Pollock, Kenneth H. (2017). Design and Analysis of Ecological Field Studies. Diunduh pada tanggal $26 \quad$ januari 2017 pada http://www4.ncsu.edu/ pollock/pdfs/EcoD\%202008\%20L1.pdf.

Slameto (1995). Belajar dan Faktor-faktor yang Mempengaruhinya.Jakarta: Bina Aksara.

Sobur, A. (2003).Psikologi Umum.Bandung: Pustaka Setia

Sugihartono, dkk. (2007). Psikologi Pendidikan.Yogyakarta: UNY Press

Sumaatmadja, N., (1984), Metodologi Pengajaran Ilmu Pengetahuan Sosial, Alumni, Bandung.

Vassala P. (2006). The Field Study As An Educational Technique In Open And Distance Learning. Turkish Online Journal of Distance Education-TOJDE 7 (4): 10-17.

Walgito, B. (2010). Pengantar Psikologi Umum. Yogyakarta: Penerbit Andi Yogyakarta. 